\title{
HIGHLIGHTS OF THE 6th INTERNATIONAL CONFERENCE ON AIR POLLUTION
}

\author{
C.J. Els
}

\section{Inleiding}

Die $2 \frac{1}{2}-$ dag simposium is goed bygewoon en 'n magdom inligting is ontleed. Dit is my uitdagende taak om sommige van die hoogtepunte van hierdie 6de Internasionale Konferensie uit te lig. Ek bedank my rapporteurs Dr. Boegman, Dr. Wells, Dr. Held, Dr. G Venter en Dr. C.W. Louw vir hulle hulp in hierdie poging.

\section{Highlights}

\subsection{Opening Addresses}

An excellent foundation was laid by both Dr. Retief and Dr. Morrison in their opening addresses.

Dr. Retief expressed the hope that one or two branches would be added to the handsome tree which is now 17 years old. In my opinion the tree has grown much more than anybody could expect over the last $2 \frac{1}{2}$ days.

Dr. Morrison emphasized that we in SA must achieve the maximum benefit with the minimum expense and emotion.

Our heterogenous society necessitates that only the most cost-effective steps be taken in controlling air pollution.

\subsection{Admiral Sharp}

Admiral Sharp is a very well-known international figure.

So much so that when I asked an IUAPPA official at the 1983 Paris Conference about Admiral Sharp's home address, he said "United Kingdom" would be quite sufficient.

Admiral Sharp, in his inimitable way, took us on a world tour of overseas practice, problems and legislation.

In so doing, he gave the nearly $80 \%$ South Africans in the audience a clear perspective of our own relative position in a truly international scene.

On the IUAPPA front we attach great value to our status as a full member. Possibly because of this, I could not help wondering if the constitutional change in allowing Governments of countries into IUAPPA would not have the effect of sharply increasing the political and emotional interplay within IUAPPA - the first to the detriment of SA and the second to the detriment of all clear-thinking, objective member countries.

I am sorry to say there is no truth in the old saying that Politicians lie, but it doesn't matter because nobody listens!
We in SA have been involved in giving assistance to our neighbouring countries and are more than willing to continue sharing expertise, internationally.

\subsection{Major Topical Issues}

Here I am referring to the issue of lead, the acid rain problem and to the macro/global impact of pollution. These issues featured in many of the papers presented, but were expertly highlighted by our plenary speakers.

\subsubsection{Lead}

As borne out by papers such as Dr. Waldrons paper, lead is not a substance to be taken lightly - although it helps to add a bit of humour to such a heavy problem. Dr. Waldron feels that the emotional emphasis on petrol may have diverted the attention from much more serious sources of lead which could have been controlled at lower cost. It was reassuring to heat that measurements are being done in SA to prevent us from going the way the Roman Empire did.

The Minister indicated clearly that our current lead levels do not necessitate drastic measures, and steps are planned to make sure it stays that way.

We should keep an open mind on all the data which becomes available and make sure that we do not over-react and thus jeopordise a proper cost-benefit approach.

\subsubsection{Acid Deposition}

Our main speaker on this subject, Prof. Rentz, has sofar had a career which, I think has made the Recording Angel think seriously about taking up shorthand.

Prof. Rentz's most excellent Presentation is still fresh in our minds and I do not want to say too much on it. He outlined the very serious damage caused by acidic deposition in Germany. The irreversible nature of this damage to especially forests and structures is quite shocking and I think that Prof. Rentz has put the cat among the SA pigeons with his paper.

All our overseas guests assure me that we have all the ingredients for the formation of acidic rain in certain areas. The extremely high cost of desulphurization and $\mathrm{No}_{\mathrm{x}}$ control will make SA think very carefully before taking remedial action. We trust that sufficient research data will be available timeously to make the correct, cost-effective decision. 


\subsubsection{Global Impacts of Air Pollution}

The fascinating work done by Drs. Rassmussen and Bach have made a great impact on the audience - as such macro, long term predictions normally do.

Talk of the greenhouse effect has been with us for quite some time, but it was very interesting to learn that trace gases can shortly contribute as much as $\mathrm{CO}_{2}$ to the greenhouse effect.

I just pity the poor Dutch if the sea level should rise by 6 metres!

\section{$2.4 \quad$ Major Undercurrents of the Conference}

\subsubsection{People Pollution}

In his conclusion of the Third Conference in 1973, Mr. Lever stressed that what we have to control is people pollution. This was again a major undercurrent of this Conference where many of our speakers pointed out that most of the important pollutants result from our quest for FOOD and ENERGY. This quest is directly related to the population explosion and I have seen very little progress in curbing this world-wide problem over the last decade!

\subsubsection{Power Generation}

No less than $37 \%$ of our papers dealt either directly or indirectly with the pollution problems from power stations.

To date the SA resistance to pressures to install baghouses has been at least as high as the resistivity of our fly-ashes.

At this conference we have heard many of the Pro's and Con's of baghouses vs. elctrostatic precipitators and only the future will tell whether the SA approach was the most cost-effective.

What has become clear, is that we are far too ignorant of the micro properties of our fly-ashes which can become macro-problems in successfully designing and operating both elecrostatic precipitators and bagfilters.

\subsubsection{Education}

We heard a powerful, musically assisted plea for the creation of a post-graduate chair in Environmental Engineering at the University of Pretoria.

As we are sadly lacking in this respect and are still very reliant upon overseas technology and expertise, this plea deserves thorough consideration.

It takes time to complete studies and te sooner we start, the better because the need for such graduates is increasing rapidly.

\subsubsection{Navorsing}

Hierdie Konferensie het duidelik getoon dat ons navorsers met 'n karige R3 miljoen per jaar tot hul beskiking dusver daarin slaag om te kan saam gesels met baie van ons oorsese besoekers. Dit is merkwaardig en 'n goeie voorbeeld van koste-doeltreffende aanwending van skaars hulp-bronne. Dit kan egter nie ad infinitum so aangaan nie, want die vrae hoop op en antwoorde moet bytyds gekry word vir sinvolle besluitneming. Binnekort sal meer geld en hulpbronne op 'n sinvolle wyse in navorsing moet gaan.

\subsubsection{Meteorologie}

Die referate deur Surridge, Boegman, Von Gogh, Cosgrove, Mulholland, Burger, Lu en Chen onderstreep steeds die behoefte aan werkbare voorspellings modelle. Dit is net nie moontlik om al die veranderlikes heeltyds te meet nie.

Die moontlike gebruik van windkrag (bespreek deur Diab) was heel interesant.

Ek is seker baie Kapenaars sal graag wil hê dat Dr. Jury sy referaat in die moederstad kom herhaal.

Miron en Held se referate het interessante verskynsels oor droë koeltorings uitgelig.

\subsubsection{Lug Kwaliteit}

Uitstekende referate is gelewer in hierdie sessie. Metings toon duidelik dat groot sukses behaal is in die bekamping van partikulëre besoedelstowwe en dat die klem nou verskuif na gesagtige uitlate.

Dr. Karrasch se referaat onderstreep die lang termyn effekte van besoedelstowwe en die feit dat herstel van skade baie lank kan neem.

Turner se referaat het geraak aan 'n saak wat heelwat meer aandag verdien, nl. die baie hoë konsentrasies van besoedelstowwe in ons swart stedelike atmosfere.

Wells kom tot die ietwat verrassende gevolgtrekking dat besoedelingsvlakke gedurende somer maande net so hoog kan wees as gedurende wintermaande.

Uit Taiwan waar $80 \%$ van hul voertuie motorfietse is, kom die interessante feite oor hoë uitlate uit twee-slag enjins!

Walker se referaat is weer 'n voorbeeld van hoe ons navorsers met die minimum hulpbronne die taak gedoen kry.

\subsubsection{Tegnologie}

Soos gewoonlik het hierdie sessie 'n uitstekende opvoedings aspek vir ons in SA ingehou. 
Die referate oor elektrostatiese presipitasie, sakfilters, filter media en reuk bekamping het verdere boustene verskaf vir besluitneming op owerheids en nywerheidsvlakke.

Ons is baie dank verskuldig aan die verskaffers van toerusting wat so ver gekom het om ons ingelig te hou.

\subsubsection{Legislation}

The two papers by Mr. Lloyd and Mr. Tucker gave us an insight into the implementation of dust control and diesel vehicle control measures. Such papers can only create better understanding and consequently better co-operation by all concerned.

The paper by Dr. Basson and Mr. Eaterbrook outlined NACA's very important role as prime communicator and co-ordinator in all air pollution matters.

If further refined, the cost-benefit approach outlined by Dr. Boegman could develop into a powerful decision-making tool in SA.

\section{CONCLUSION}

The past $2 \frac{1}{2}$ days has given all of us a very good insight into the world-wide air pollution scenario.

Many questions remain to be answered, and so Dag Hammarskjöld said: "In the last analysis, it is our conception of death which decides our answers to all the questions that life puts to us".

I think this quotation explains to some extent why different states within a single country approach problems in such different ways. Let us also bear in mind that the only exact science is hindsight!

A major highlight of this conference has been the attendance and participation of our guests from overseas and countries in our own continent. This has enabled us to strengthen our technical and friendship bonds with all of them.

Many more of our authors deserve to be mentioned in a concluding talk such as this. They have gone to a great deal of trouble to present us with quality papers and have thus kept the standard of this 6 th Conference at a very high level. 